\title{
Rat C6 glioma cell motility and glioma growth are regulated by netrin and netrin receptors unc5B and DCC
}

\author{
Margaret Durko*, Zaf Koty, Lixia Zhu, Nathalie Marçal, Timothy E. Kennedy and Josephine Nalbantoglu \\ *Correspondence: margaret.durko@mail.mcgill.ca \\ Montreal Neurological Institute, Department of Neurology and Neurosurgery, McGill University, Montréal, Québec, Canada.
}

\begin{abstract}
Background: Cell migration plays a key role in tumor invasion and metastasis. Deleted in colorectal cancer (DCC) and the unc5 homologues are receptors for secreted netrins that regulate cell and axon migration, cell adhesion, and tissue morphogenesis. Altered netrin and netrin receptor expression has been reported in aggressive tumors, including glioblastoma. Here, we investigated the involvement of netrin and netrin receptors in glioma cell migration and tumor formation using rat C6 glioma, a counterpart to human glioblastoma multiforme.

Methods: We used Western blot analysis and RT-PCR to characterize netrin and netrin receptor expression in rat C6 glioma. C6 motility was assessed using a transfilter chemotaxis assay. To study the effect of ectopic DCC expression on C6 glioma cells, we determined the in vivo growth of three different cell populations after intracerebral implantation in rats. Three-dimensional reconstruction of tumors was performed to calculate tumor volume.

Results: We determined that rat C6 glioma cells express netrin-1, netrin-3, and the netrin receptor unc5B, but not DCC. Using transfilter migration assays we demonstrated that C6 cells migrate away from a source of netrin-1, consistent with chemorepulsion signaled by Unc5B. In the absence of a gradient of netrin, disrupting netrin protein secreted by these cells reduced C6 cell motility, suggesting that autocrine netrin promotes C6 cell motility in this assay. Ectopic expression of DCC reduced the rate of migration in the absence of any gradient, and reduced the rate of directional cell migration up a gradient of laminin-1. Intracerebral implantation of glioma cells engineered to express full-length DCC (pCEP4-DCC) resulted in reduced tumor volumes and sharp borders between tumor and brain tissue, compared to tumors arising from parental or pCEP4 vector-transfected cells.

Conclusions: These results provide evidence that netrin and Unc5B may promote cell motility by weakening interactions between tumor cells and that loss of DCC promotes growth and invasion of rat glioma.

Keywords: Deleted in colorectal cancer, netrin, netrin receptor, cell migration, glioma, invasion
\end{abstract}

\section{Introduction}

Malignant gliomas are primary brain tumors characterized by rapid and invasive growth that progress to highly aggressive glioblastoma multiform (GBM) [1,2]. Their diffuse and infiltrative growth throughout the brain parenchyma makes these tumors difficult to manage by surgery and chemotherapy. An important therapeutic aim is to understand the molecular mechanism responsible for aggressive cell migration, in order to develop treatments that can limit invasion [2].

Tumor development toward aggressive, invasive, and metastasizing phenotypes is a multi-stage process [3] and lost or diminished DCC expression is associated with tumor progression. DCC, a putative tumor suppressor, was identified on the basis of allelic deletions and diverse somatic mutations in this gene in human colorectal neoplasia $[4,5]$. DCC is down- regulated or lost by various genetic and mutational events in many advanced tumors of different origin, including neuroblastoma [6,7], ovarian cancer [8], breast cancer, prostate cancer, melanoma [9,10], and highly invasive glioblastoma multiform $[\mathbf{9}, \mathbf{1 1}, \mathbf{1 2}]$. Experimental studies support DCC tumor suppressive abilities. For example, ectopic expression of full-length DCC in transformed cells inhibited tumorigenicity $[13,14]$. Loss of function point mutations in Frazzled, the Drosophila orthologue of DCC, resulted in a cancer-like phenotypes in flies [15]. DCC has been proposed to function as a dependence receptor, activating apoptosis in the absence of netrin-1 [16]. Introducing a point mutation in DCC that disrupts this pro-apoptotic function in mouse increased tumor severity in a genetic background predisposed to the development of intestinal neoplasia [17]. Furthermore, conditional deletion of DCC promoted metastasis in a mouse model of mammary carcinoma [18]. Despite such studies, the underlying mechanism by which DCC inactivation contributes to cancer progression and an invasive phenotype remains poorly understood.

Early studies carried out in C. elegans and the embryonic vertebrate nervous system demonstrated that DCC functions as a netrin receptor to direct cell and axon migration [1922]. In vertebrates, DCC, the DCC paralogue neogenin, and the Unc5 homologues, are netrin receptors that regulate chemotropic migration during development [22]. Netrin-1 and netrin receptors are also expressed in many adult tissues, but their contribution to function in adult tissues remains poorly understood [23-26].

The extracellular domains of DCC and neogenin are composed 
of IgG repeats and fibronectin type III repeats, similar to cell adhesion proteins like neuronal cell adhesion molecule (NCAM) [4]. Both DCC and neogenin influence cell-substrate and cellcell adhesion [24,26-30]. Outside the nervous system, netrin-1 and netrin receptors contribute to tissue morphogenesis, including development of lung [31,32], pancreas [33], and the vascular system [34]. DCC signaling regulates cytoskeletal organization to control cellular motility and adhesion [22].

In addition to DCC and neogenin, four Unc5 homologue netrin receptors, Unc5A-D (also known as unc5H1-H4), are expressed in vertebrates [22]. Unc5 homologues also regulate cell migration and morphogenesis during development [31,34-37], and altered Unc5 homologue expression has been detected in various cancers [38-40].

Netrins, the ligands for DCC and Unc5 homologues, are a small family of proteins related to laminins [22]. Three secreted netrins are expressed in mammals netrin-1, -3 and -4 . Netrins are bifunctional, acting as chemoattractant and chemorepellent migratory cues for different cell types [41-45]. DCC is required for chemoattraction, while Unc5 homologues signal repellent responses to netrin-1, in some cases in collaboration with DCC as a netrin receptor complex [22]. Netrin-1 also influences cell survival [46], proliferation [37], tissue morphogenesis [33], cell adhesion and tumorigenesis $[13,29,47]$. Reduced expression of netrin- 1 has been detected in brain tumors and neuroblastoma [48], and netrin-1 is implicated in cancer cell invasion and tumor progression $[13,46]$.

We reported that netrin and DCC influence human glioblastoma cell migration, and that DCC slows the rate of spontaneous cell migration [47]. Here, using the rat C6 glioma cell line, we provide evidence for an autocrine function of netrin acting via Unc5B that promotes cell dispersion, whereas ectopic DCC expression restrains cell movement and intracerebral glioma growth.

\section{Materials and methods \\ Cell culture}

Rat C6 and C6lacZ glioma cells, and the U87 human glioblastoma cell line (ATCC, Rockville, MD) were grown as monolayer cultures in DMEM (Invitrogen, Burlington, ON) supplemented with $10 \%$ heat-inactivated foetal bovine serum (FBS, Invitrogen, Burlington, ON), glutamax-1 supplement (Invitrogen, Burlington, ON), and penicillin/streptomycin (Invitrogen, Burlington, ON). Cell lines were maintained at $37^{\circ} \mathrm{C}$ in $5 \% \mathrm{CO}_{2}$.

Rat C6lacZ glioma cells were modified by double transfection with pUT535 plasmid containing the Escherichia coli lacZ gene encoding $\beta$-galactosidase ( $\beta$-gal) together with pRCRSV encoding the neomycin phosphotransferase gene conferring resistance to G418 [49]. Cells were selected using Geneticin $(600 \mu \mathrm{g} / \mathrm{ml})(\mathrm{G} 418$; Invitrogen) and periodically monitored using $X$-gal to ensure continuous lacZ expression. LacZ expression facilitated tumor cell detection in vivo.

\section{Transfection, cell Lysates, conditioned media} Full-length rat DCC from pBS-DCC (clone D4-1, GenBank U68725) was subcloned into PCEP4 (Invitrogen) [50]. For in vivo experiments, C6lacZ cells were transfected with the control PCEP4 vector or the DCC expression construct pCEP4-DCC. For in vitro cell migration assays, $\mathrm{C} 6$ cells were transfected with the control pGFP vector encoding green fluorescent protein or the expression construct PDCC-GFP encoding DCC tagged at its C-terminus with GFP [50]. Transfections were carried out using lipofectamine (Invitrogen, Burlington, ON) according to the manufacturer's instruction. Stable cell transfectants (C6lacZ pCEP4 and C6lacZ pCEP4-DCC) were selected using hygromycin at $400 \mu \mathrm{g} / \mathrm{ml}$. C 6 cells transfected with pGFP or pDCC-GFP were selected using Geneticin (G418; Invitrogen). For conditioned media, cells were grown to $80 \%$ confluence, rinsed, and replaced with serum-free DMEM that was collected after $48 \mathrm{hrs}$. For cell lysates, cells were grown in $100 \mathrm{~mm}$ tissue culture dishes to $80 \%$ confluence, rinsed with PBS, and lysed in $0.6 \mathrm{ml}$ of hot sample buffer $(60 \mathrm{mM}$ Tris/ $\mathrm{HCl}, \mathrm{pH} 6.8,2 \% \mathrm{SDS}$, $10 \%$ glycerol, $100 \mathrm{mM} \mathrm{DTT}$ ) and denatured at $98^{\circ} \mathrm{C}$ for $5 \mathrm{~min}$. Lysates were stored at $-20^{\circ} \mathrm{C}$ until used.

\section{Western blot analysis}

Proteins were separated by 7\% SDS-PAGE and electro-blotted to nitrocellulose (Hybond ECL, Amersham Pharmacia, QC). The membrane was blocked for one hour with $5 \%$ skim milk powder and 3\% bovine serum albumin (BSA) in $150 \mathrm{mM}$ $\mathrm{NaCl}, 50 \mathrm{mM}$ Tris- $\mathrm{HCl}, \mathrm{pH} 7.5$ (TBS) containing $0.1 \%$ Tween 20 (TBST). Blots were probed overnight either with a mouse monoclonal antibody against $\mathrm{DCC}_{\mathrm{IN}}(0.5 \mu \mathrm{g} / \mathrm{ml}, \mathrm{G} 97-449 ; \mathrm{BD}$ Biosciences PharMingen, San Jose, CA), PN2 affinity purified rabbit polyclonal against netrin-1 and netrin-3 (diluted 1/500) [23,51], polyclonal goat anti-Unc5H2 (diluted 1/10000; $R \& D$, Minneapolis, $M N$ ), or polyclonal goat anti-Neogenin (C-20, diluted 1/500; Santa Cruz Biotechnology, CA), in blocking solution (5\% skim milk powder, 3\% BSA, in TBST). Immunoreactivity was visualized using an ECL-Western blot detection kit (NEN, MA).

\section{RT-PCR}

Total cellular RNA was isolated from C6 glioma cells, adult rat brain, and E13-14 embryonic rat heads, using Trizol (Life Technologies, MD), and reverse transcription followed by PCR were performed sequentially in the same tube using OneStep RT-PCR kit (QIAGEN Inc.). Primers were annealed at $55^{\circ} \mathrm{C}$ to amplify netrin-1 (320 bp), dcc (470 bp), unc5A (405 bp), unc5B (411 bp), unc5C (394 bp), and unc5D (401 bp); $52^{\circ} \mathrm{C}$ for netrin-3 (311 bp); and $67^{\circ} \mathrm{C}$ for neogenin (1088 bp). The following primer pairs were used: rat netrin-1, $5^{\prime}$-ggagcctcgctgttgtactc- $3^{\prime}$ and $5^{\prime}$-ggccatggtcctgagactta-3'; rat netrin-3, $5^{\prime}$-gttgcaagcccttccactac-3' and 5'-ggtggtttgattgcaggtct-3'; rat neogenin, $5^{\prime}$-aactgcagaaagcggactcctctgataaaatg- $3^{\prime}$ and $5^{\prime}$-tccccgcggccggctccttcctaaa-3'; rat dcc, 5'-ccggaattcagtgaaggaccaacagc-3' and 
5'-gtccgctcgagcaatgcatgtcaaaagg-3'; rat unc5A, $5^{\prime}$-cacgtaattgaacgcagcac-3' and 5'-acaggtgtagttggccgtgt-3'; rat unc5B, 5'-accagaggatgcctacatcg-3' and $5^{\prime}$-ttcttgagccattccacctc-3'; rat unc5C, 5'-tgttcgggcctgaagattac-3' and $5^{\prime}$-gtggaccagccaccattaac-3'; rat unc5D, 5'ccgggaggtgtttatcaatg $-3^{\prime}$ and $5^{\prime}$-ctgacaggctcctcctcttg-3'.

\section{Transfilter chemotaxis assay}

Cells were plated on polycarbonate transwell cell culture inserts $(6.5 \mathrm{~mm}$ diameter with $8 \mu \mathrm{m}$ pore size, Corning) at $5 \times 10^{4}$ cells $/ 100 \mu \mathrm{l}$ per filter and the filters were placed in 24 well plate over $0.6 \mathrm{ml}$ of medium. DMEM with $0.2 \%$ BSA, 100 $\mathrm{U} / \mathrm{ml}$ penicillin, $100 \mu \mathrm{g} / \mathrm{ml}$ streptomycin, and $2 \mathrm{mM}$ glutamax was the base medium used for all assay conditions. Where applicable, laminin-1 (10 $\mathrm{gg} / \mathrm{ml}$; BD Biosciences, Bedford, $\mathrm{MA})$, netrin function -blocking antibody $\left(100 \mu \mathrm{g} / \mathrm{ml}\right.$ netrin $\mathrm{FB}^{\prime}$ PN3, rabbit, $[23,51])$, control rabbit pre-immune lgG $(100 \mu \mathrm{g} /$ ml, RblgG; Invitrogen, ON), recombinant human Unc5H3/Fc chimera (5 $\mu \mathrm{g} / \mathrm{ml}$, R\&D Systems Inc., Minneapolis, MN), or recombinant netrin-1 protein purified from a 293-EpsteinBarr virus nuclear antigen (EBNA) cell line secreting netrin-1, as described [29], was added to the base medium. Following migration, cells on the upper side of filter were scraped off, and the cells attached to the lower side of the filter fixed with $0.125 \%$ glutaraldehyde $\left(25 \mathrm{~min}\right.$, at $\left.4^{\circ} \mathrm{C}\right)$. Filters were rinsed with PBS and cell nuclei stained with Hoechst dye. Three transwell inserts were used per condition. Four images of each filter were captured using a $10 \mathrm{X}$ objective and nuclei counted using Northern Eclipse software (Empix Imaging, TO). The results are presented as the mean number of cells migrating per condition.

\section{Intracranial injection}

Studies using animals were carried out according to the guidelines of the Canadian Council on Animal Care. Stereotactic injections were made as previously described [49]. Six weekold female Sprague-Dawley rats (Charles River, Canada) were anesthetised with sodium pentobarbital (25 mg/ $\mathrm{kg}$ ) administrated intraperitoneally and the animal's head immobilized in stereotactic apparatus (David Kopf Instruments). An incision was made in the skin to identify bregma on the exposed skull and a burr hole drilled $1 \mathrm{~mm}$ anterior and $3 \mathrm{~mm}$ lateral to bregma. Cell suspensions $\left(1 \times 10^{4}\right.$ cells in 5 $\mu$ l of HBSS) of parental C6lacZ, C6lacZpCEP4 -empty vector control, or C6lacZpCEP4-DCC (expressing DCC) were injected stereotactically over a 10 min period using a Hamilton syringe at a depth of $3.5 \mathrm{~mm}$. Six animals were used per cell type.

\section{Brain tumor analysis}

Two weeks after tumor cell injections, rats were euthanatized, brains removed, and quickly frozen in isopentane chilled with liquid nitrogen. Ten $\mu$ m-thick coronal sections were mounted on glass slides and stained for $\beta$-gal activity in the presence of $x$-gal substrate, as described [49]. Tumor volumes were calculated using the formula $a \times b^{2} \times 0.4$ (if $b<a$ ) or $a^{2} \times b \times$ 0.4 (if $a<b$ ), in which a represents the length of tumor from the beginning to the end and $b$ represents the length of the biggest tumor section.

\section{Statistical analysis}

All data are reported as mean \pm SE. Unpaired Student's t-tests were used for statistical comparisons of the mean values between the data. A value of $p<0.05$ denotes statistical significance. Statistical analysis was performed with Prism software (Graph pad).

\section{Results}

\section{C6 glioma cells express netrin and netrin receptors}

Netrin and netrin receptors are essential for normal neural development [22], and are also implicated in cancer progression in various tumors, including tumors of the brain $[6,40,48]$. To address the possibility that netrin and netrin receptors regulate glioma cell migration, we first characterized their expression in C6 glioma. Cell culture medium conditioned by C 6 glioma cells was analyzed for netrin expression by Western blot using polyclonal PN2 antibodies that bind netrin-1 and netrin-3 [51]. An $75 \mathrm{kDa}$ band was detected, corresponding to full length netrin protein (Figure $1 \mathrm{Aa}$ ). RT-PCR analysis detected $\mathrm{C} 6$ cell expression of netrin-1 and netrin-3 mRNAs (Figure 1B). The single band on the Western blot likely corresponds to netrin-1 and netrin-3 due to their similar molecular mass [52]. Both netrin- 1 and netrin-3 bind DCC and the Unc5 homologues and exhibit similar functions [22]. DCC protein was not detected in parental C6lacZ cell extracts analyzed by Western blot using a monoclonal antibody against the intracellular domain of DCC $\left(D_{C C_{I N}}\right.$ ) (Figure 1Ac). This antibody detected a band of 195 kDa corresponding to DCC in C6 and C6lacZ cell lysates that were transfected with the DCC expressing constructs pDCC GFP and pCEP4-DCC, respectively. DCC immunoreactivity was not detected in cells transfected with control vectors pGFP and pCEP4 (Figure 1Ac). Anti-DCC IN $_{\text {also detected }}$ DCC immunoreactivity in cell extracts of U87 glioblastoma cells, which served as a positive control for DCC expression (Figure 1Ac) [47]. The DCC paralogue neogenin was not detected in C6 glioma cell extracts assayed using Western blotting and the Neo C-20 antibody (not shown). Consistent with this, RTPCR did not detect neogenin or DCC mRNA expression in C6 glioma cells (Figure 1B).

Western blot analysis of C 6 cell lysate with an antibody against Unc5B detected an $\sim 135 \mathrm{kDa}$ band (Figure 1 Ab), consistent with previous studies [53]. RT-PCR analysis detected C6 cell expression of Unc5B mRNA (Figure 1B). Using the respective primers, netrin and netrin receptor expression was demonstrated in adult and embryonic rat brain homogenates as positive controls (Figure 1B).

Netrin and netrin receptors regulate $\mathrm{C} 6$ cell migration These findings establish that rat $\mathrm{C} 6$ glioma cells express 
A

a.

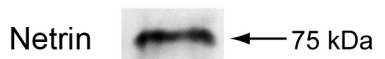

b.

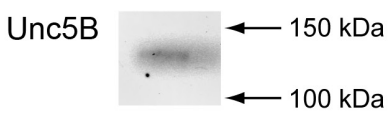

C.

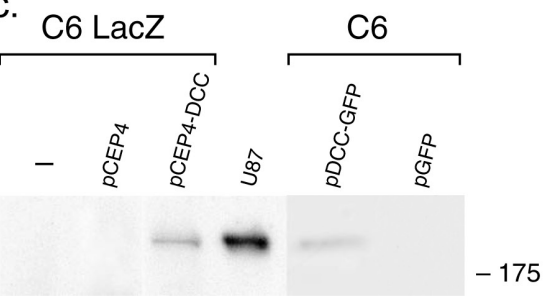

B
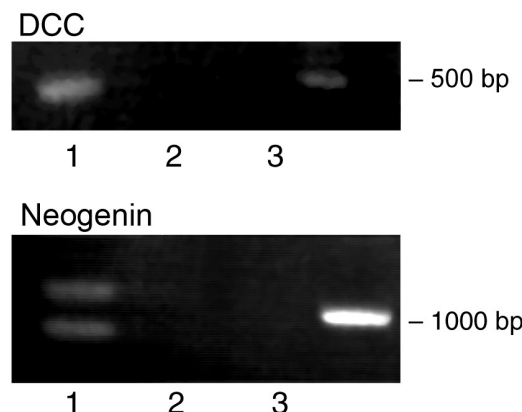

Netrin-1

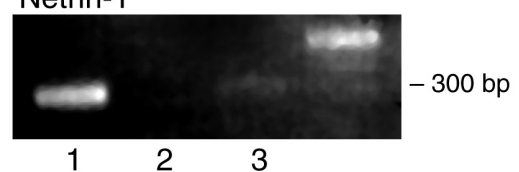

Netrin-3
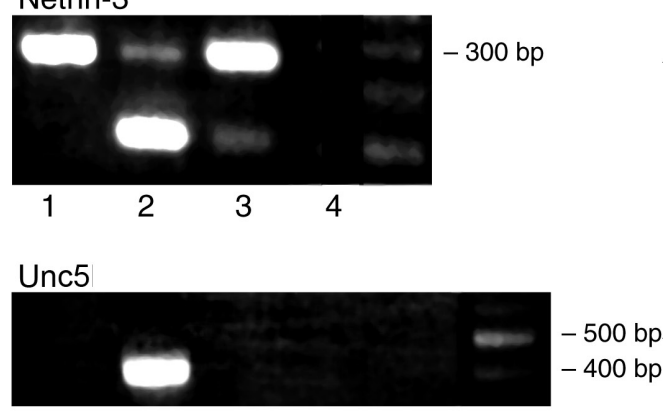$$
\text { A }
$$

C

$\mathrm{D}$

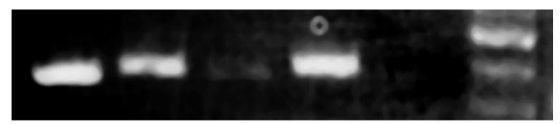

$-500 \mathrm{bp}$ $-400 \mathrm{bp}$

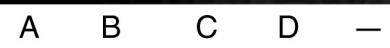

Figure 1. Netrin and netrin receptor expression by C6 glioma cells.

A. Western blot analyses of proteins in conditioned media and cell lysates:

a. Full-length netrin protein $(\mathrm{N})(\sim 75 \mathrm{kDa})$ was detected in conditioned medium with rabbit PN2 antibody, which binds netrin-1 and netrin-3. b. A band corresponding to Unc5B protein $(\sim 135 \mathrm{kDa})$ was detected in whole cell lysate using a goat polyclonal antibody against Unc5B. c. Anti-DCC ${ }_{\mathrm{IN}}$ detected full-length DCC protein $(\sim 195 \mathrm{kDa})$ in whole cell lysates prepared from either C6LacZ cells transfected with a plasmid carrying the DCC expression cassette pCEP4-DCC or from C6 cells transfected with a plasmid encoding DCC tagged with GFP at its C-terminus (pDCC-GFP). DCC protein was not detected in whole cell lysates prepared from parental C6 LacZ cells (-) or in the two control cell lines: C6 LacZ pCEP4 and C6 pGFP. DCC protein was readily detected in extracts of U87 human glioblastoma cells, which served as a positive control. Molecular mass markers $(\mathrm{kDa})$ are indicated on the right.

B. RT-PCR analysis of total RNA:

Total cellular RNA isolated from C6 cells and embryonic rats was subjected to RT-PCR using primers specific for netrins and netrin receptors. Netrin-1 and netrin-3 expression are shown in lane 3 (Netrin-1, Netrin-3 panels). Unc5B was the only Unc5 family member detected (Unc5 top panel, lane B). In panels labelled DCC, Neogenin and Netrin-1: lane 1- RNA from embryonic day 13 (E13) rat whole head, lane 2- no RNA, and lane 3- RNA from C6 cells. In the panel labelled Netrin-3: lane 1- RNA from embryonic day 13 (E13) rat whole head (E13), lane 2- RNA from adult rat brain, lane 3- RNA from C6 cells and lane 4- no RNA. In the panel labelled Unc5, C6 cells are shown on top and adult rat brain on the bottom. Lane $\mathbf{A}$ is unc5A, lane $\mathbf{B}$ is unc5B, lane C is unc5C, lane D is unc5D and lane (-) is no RNA. 100bp ladder is shown in the last lane in each panel, with size indicated on the right. 

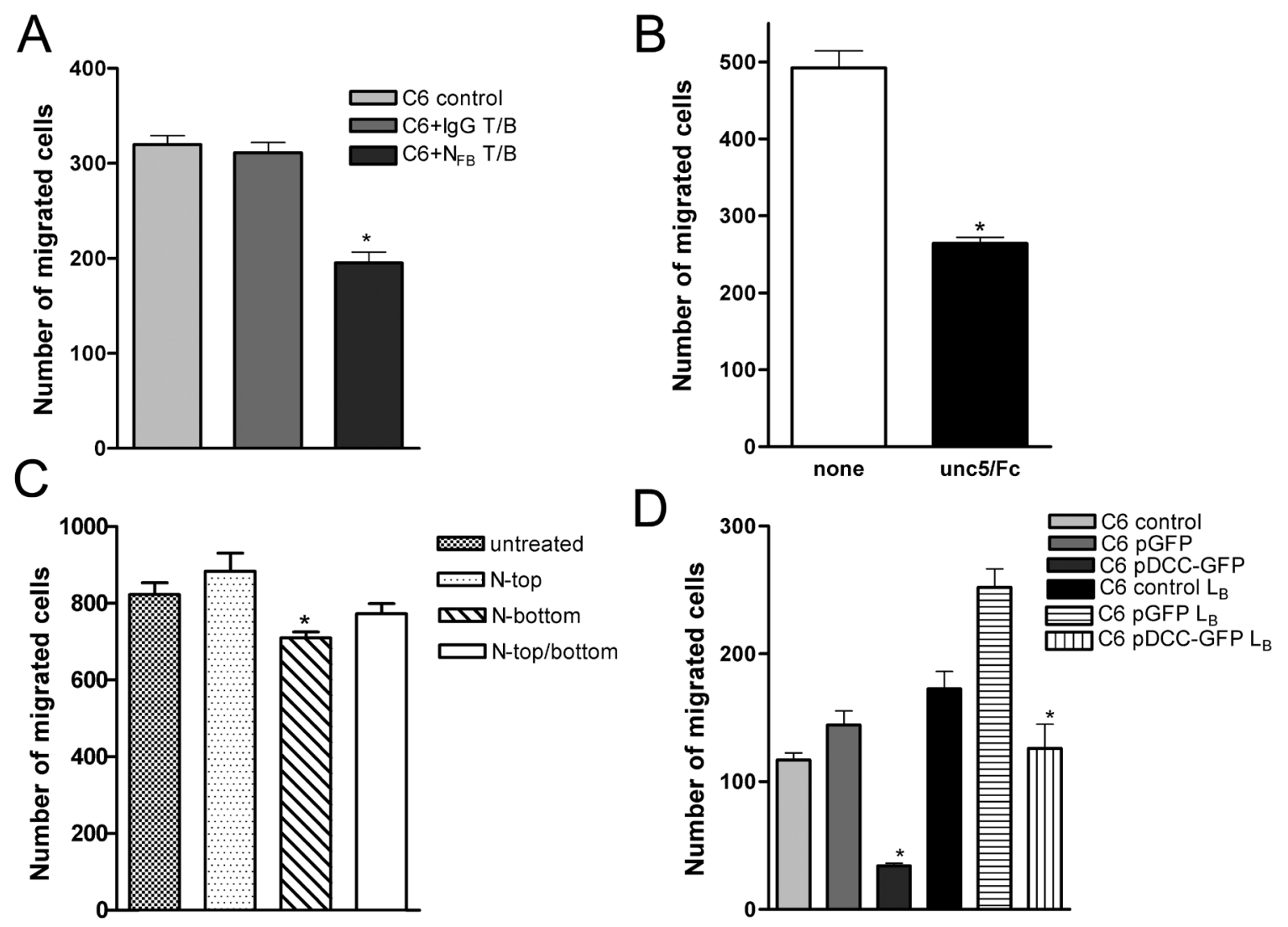

Figure 2. Netrin and netrin receptors Unc5B and DCC regulate C6 cell migration.

A. Autocrine netrin increases C6 motility. Addition of $100 \mu \mathrm{g} / \mathrm{ml} \mathrm{PN} 3$ netrin function-blocking antibody $\left(\mathrm{N}_{\mathrm{FB}}\right.$ $\mathrm{T} / \mathrm{B}$ ) to the top and bottom compartments in the transfilter chemotaxis assay significantly decreased glioma cell migration compared to control cell migration either in medium alone or in the presence of non-immune rabbit $\operatorname{IgG}(\operatorname{IgG} \mathrm{T} / \mathrm{B})$ added to the top and bottom compartments. ${ }^{*} \mathrm{p}<0.0001$ vs. control cell migration in the presence of IgG. B. Disrupting Unc5 function inhibits C6 cell motility. Addition of recombinant rat Unc5C/Fc chimera $(5 \mu \mathrm{g} / \mathrm{ml})$ to the top and bottom compartment in a transfilter assay significantly reduced spontaneous migration compared to cell migration in medium alone $\left(^{*}, \mathrm{p}<0.0001\right.$ vs. untreated control). C. A gradient of Netrin- 1 repels C6 cell migration. C6 cells were placed in the top chamber in a transfilter assay and cell migration was assessed in the presence of a gradient of exogenous netrin-1 $(10 \mu \mathrm{g} / \mathrm{ml})$. Addition of netrin-1 to the lower chamber (N-bottom) significantly reduced the number of cells migrating from top to bottom $\left({ }^{*}, p<0.05\right.$ vs. untreated control). Although netrin-1 placed in the top chamber (N-top) together with C6 cells increased the mean number of cells migrating to the bottom chamber, this difference did not reach statistical significance. The addition of netrin-1 to both the top and bottom compartments resulted in migration that was not significantly different from control (N-top/bottom). D. DCC suppresses glioma cell migration. C6 cells expressing DCC (C6 pDCC-GFP) exhibited significantly less migration relative to control cells (C6 pGFP). Both spontaneous migration in the absence of a gradient (pDCC-GFP) and migration up a gradient of laminin $-1\left(\mathrm{~L}_{B}\right)$ were significantly reduced $\left({ }^{*}, \mathrm{p}<0.0001\right.$ vs. C6pGFP or C6pGFPL $\mathrm{L}_{B}$ control). In each transfilter chemotaxis assay cells were plated in the top compartment $\left(5 \times 10^{4}\right.$ cells per filter) and allowed to migrate for 48 hours. Where applicable, laminin-1 $\left(\mathrm{L}_{\mathrm{B}}\right)$ attractant was added at $10 \mu \mathrm{g} / \mathrm{ml}$ to the lower compartment. Migration is expressed as the average number of migrated cells +/- SEM.

netrin-1, netrin-3 and unc5B, but not DCC or neogenin. To assess the possibility that autocrine expression of netrins might affect C6 motility, cells were allowed to migrate in a transfilter chemotaxis assay as described [47], in the absence of an exogenous cue. Briefly, cells were plated on the upper surface of the filter and allowed to migrate through the porous membrane. Following migration, the residual cells were scraped off the top surface of the membrane and the cells that had migrated to the opposite side of the membrane were fixed, stained and counted. In the presence of PN3 netrin function-blocking antibody $\left(\mathrm{N}_{\mathrm{FB}}\right)$ added to the top and bottom compartments, C6 migration was significantly slower than cells migrating in medium alone or in the presence of control IgG (Figure 2A). Thus, disrupting endogenous netrin-1 and netrin-3 function decreased the rate of spontaneous migration, consistent with netrin expression by $\mathrm{C} 6$ cells exerting an 
autocrine effect that promotes movement.

C6 cells express Unc5B and were therefore challenged in the transfilter assay by having them migrate in the presence of an unc $5 \mathrm{H} 3 / \mathrm{Fc}$ chimera (a fusion of a human IgG constant region with Unc5C ectodomain), added to both the top and bottom compartments. This chimeric protein functions as a competitive antagonist of netrin binding to Unc5 homologue netrin receptors. Addition of the Unc5H3/Fc chimera to both the top and bottom compartments of the transfilter assay resulted in significantly slower C6 cell migration (Figure 2B), consistent with autocrine expression of netrin promoting cell motility in an Unc5 homologue dependent manner.

Unc5 homologues have been proposed to function as dependence receptors that trigger cell death in the absence of netrin-1 $[\mathbf{5 4 , 5 5}$. This raises the possibility that the changes in cell migration detected in the transfilter assay could result from altered cell survival rather than changes in cell motility. However, following disruption of netrin function, cell survival, as measured by cell viability, was not affected, indicating that the results of the transfilter assays are due to altered cell migration (Supplement figure S1).

Transfilter migration assays were also used to assess the chemotropic directional migratory response of C6 glioma cells to a gradient of netrin-1. Addition of netrin- 1 to the bottom compartment of the migration chamber significantly reduced the number of cells migrating from the top to bottom through the porous membrane (Figure $\mathbf{2 C}$ ), consistent with a chemorepellent migratory response. Netrin-1 in the top compartment resulted in an increase in the mean number of cells migrating from top to bottom, albeit a difference that did not reach statistical significance. When exogenous netrin- 1 was added to both compartments (top and bottom), the rate of cell migration returned to the control level. These findings are consistent with $\mathrm{C} 6$ glioma cells responding to a gradient of netrin-1 as a chemotropic repellent.

To investigate the effect of ectopic DCC expression on C6 glioma cell migration, we introduced the DCC gene into C6 cells by stable transfection with an expression vector encoding DCC-GFP [50]. DCC expression was confirmed by Western blot analysis of cell extracts (Figure 1Ac, clone pDCC-GFP) using anti-DCC ${ }_{\mathbb{N}}$. Assaying transfilter migration in the absence of an imposed gradient, $C 6$ cells expressing pDCC-GFP migrated significantly more slowly than control C6 parental cells (Figure 2D). Furthermore, directional migration up a gradient of laminin-1 was also significantly reduced compared to the respective controls (Figure 2D), consistent with DCC inhibiting rat glioma cell motility.

\section{Ectopic DCC expression in C6 cells controls glioma formation in rats}

Glioma cell invasion resembles glial and neuronal migration during nervous system development, during which DCC guides migrating cells and axons in response to gradients of netrin-1 $[\mathbf{1}, \mathbf{2 0}, \mathbf{5 1}, \mathbf{5 6}]$. DCC and netrin-1 are also expressed in the adult mammalian CNS, but their contribution to adult CNS

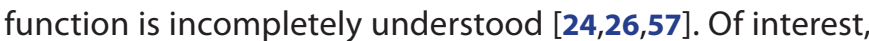
reduced expression of DCC and netrin-1 have been observed in highly malignant brain tumors $[11,48]$.

Highly invasive rat C6 cells do not express DCC and we therefore wanted to assess the influence of DCC expression on brain tumor growth. For this purpose, we used C 6 cells that were modified to express the $E$. coli lacZ gene (C6lacZ cells) encoding $\beta$-gal to facilitate cell tracking and monitor glioma growth [49]. DCC was introduced into C6lacZ cells by stable transfection with plasmid pCEP4-DCC. Cells were maintained with drug selection and clones expanded and analyzed by Western blot for DCC expression. A clone C6lacZpCEP4-DCC was selected in which an $\sim 195 \mathrm{kDa}$ band corresponding to full length DCC was detected (Figure 1Ac).

To monitor glioma growth in vivo, three cell populations (parental C6lacZ, vector- transfected C6lacZpCEP4, and DCC expressing C6lacZpCEP4-DCC cells) were intracerebrally implanted in rats. All animals developed tumors. Two weeks after cell implantation, sections containing the brain tumors were histochemically stained with X-gal to visualize the tumor cells, allowing evaluation of glioma growth and the extent of spreading into adjacent brain tissue (Figure 3). C6lacZpCEP4DCC cells generated significantly smaller tumors than the control C6lacZ and C6lacZpCEP4 cells. Tumors composed of DCC-expressing cells exhibited a smooth border and the tumor tissue itself was composed of relatively densely packed cells (Figure 3A). In contrast, tumors arising from control cells that lack DCC grew as a mass of loosely associated cells with diffuse infiltrating borders exhibiting cell migration into brain parenchyma (Figure 3B and 3C). Measurement of tumor volume indicated that the mass of tumors arising from C6lacZpCEP4DCC cells was reduced by 2 - and 4.5 -fold, compared to that of control tumors arising from C6lacZpCEP4 and C6lacZ, respectively (Figure 4). These findings provide evidence that DCC expression by $\mathrm{C} 6$ glioblastoma cells results in significantly reduced tumor mass and non-invasive borders.

\section{Discussion}

Cell migration plays an important role in normal biological processes including embryogenesis, immunity, and wound healing. Pathological changes in neoplasia cause dysfunction in the mechanisms that control cell migration, allowing tumor cells to colonize new sites. Hence, metastatic growth becomes unmanageable by surgery and therapy. Malignant gliomas are typically confined to the CNS and seldom metastasize, but they resist therapeutic treatment and are neurologically destructive due to diffuse single-cell invasion [1]. C6 rat glioma is a highly invasive tumor that is morphologically similar to human glioblastoma multiforme, the most common aggressive and infiltrative brain tumor causing neurological dysfunction and death [56]. Parenchymal invasion is a hallmark of gliomas and a therapeutic intervention that limits cell dissemination could be clinically beneficial. 


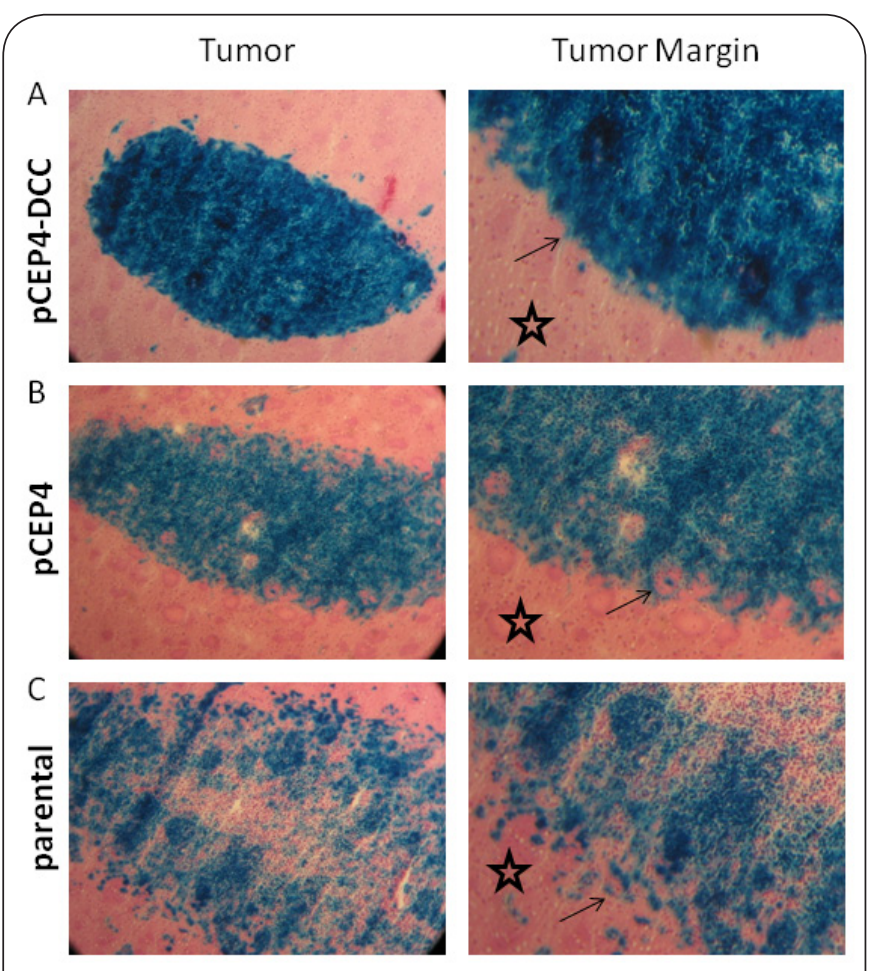

Figure 3. Ectopic DCC expression influences C6 glioma in vivo.

Tumors were established by stereotactic injection of cell suspension ( $1 \times 10^{4}$ cells in $\left.5 \mu \mathrm{l} \mathrm{HBSS}\right)$ and allowed to grow for 14 days. Brain tissue sections were stained histochemically for $\beta$-gal activity (blue) using X-gal followed by $\mathrm{H} \& \mathrm{E}$ staining. Gliomas were derived from C6lacZpCEP4-DCC cells (expressing DCC) (pCEP4-DCC), C6lacZpCEP4 cells (empty vector transfected) (pCEP4), and C6lacZ (parental cells) (parental). Tumors grown from DCC-expressing cells (pCEP4-DCC) appeared as a condensed mass of cells with smooth edges in contrast to control tumors (pCEP4 and parental), which exhibited diffuse growth with cells migrating into surrounding normal brain tissue. Arrows point to the margin of the tumor mass. Stars mark brain parenchyma. (100 $\mathrm{X}$ objective lens).

Here we provide evidence that chemotropic guidance molecules regulate $\mathrm{C} 6$ glioma cell migration. We have established that $\mathrm{C} 6$ rat glioma cells are deficient in DCC expression, but express netrin-1, netrin-3, and the Unc5B netrin receptor. We demonstrate that the inherent motility of C6 cells is influenced by autocrine secretion of netrin, and that disruption of netrin and Unc5B function inhibits cell motility. Spontaneous migration, in the absence of an external gradient, was inhibited by interfering with netrin function, and in the presence of a gradient of netrin-1, C6 cells were repelled.

Netrin-1 can function as a chemorattractant or chemorepellent, in part depending on the receptors expressed by target cells. While DCC contributes to both attraction and repulsion, the Unc5 homologues are only known to signal repulsion $[22,42-44,58]$. Our findings are consistent with Unc5B being sufficient to evoke a chemorepellent response by $\mathrm{C} 6$

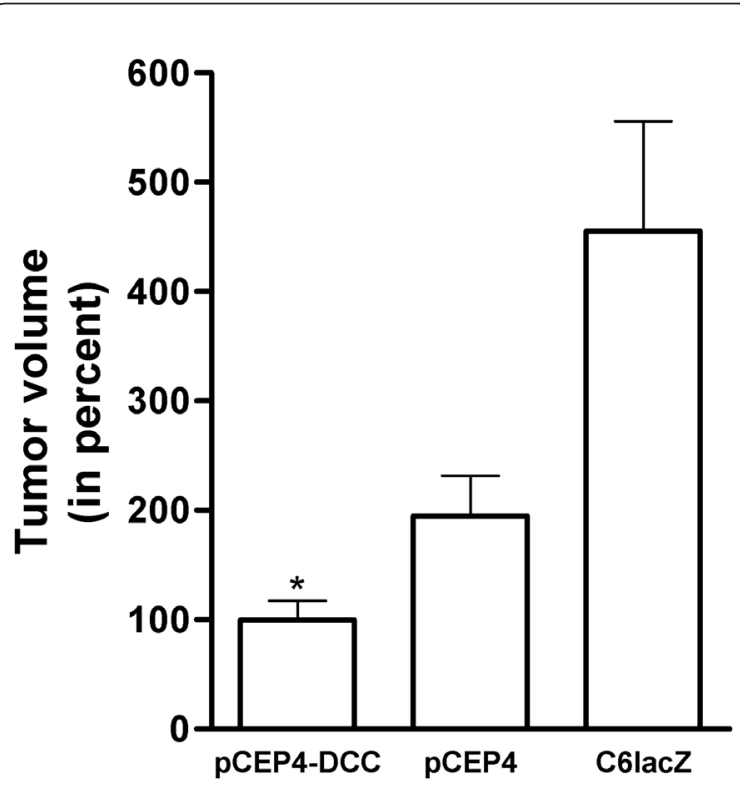

Figure 4. Ectopic DCC expression inhibits C6 glioma growth in vivo.

Intracerebral tumors were produced in rats by stereotactic injection of cell suspension ( $1 \times 10^{4}$ cells in $\left.5 \mu \mathrm{HBSS}\right)$, and allowed to grow for 14 days. Brain tissue sections were stained histochemically for $\beta$-galactosidase activity (blue) in the presence of the X-gal substrate followed by H\&E staining. Tumor mass in each of the six animals used per group was calculated according to the formula indicated in the Material and Methods. Gliomas arising from DCC-expressing C6lacZ cells (pCEP4-DCC) were significantly smaller than tumors derived from DCC-deficient cell lines, whether the parental cells (C6lacZ) or empty vector-transfected cells (pCEP4). ${ }^{\star} \mathrm{p}=0.04\left(\mathrm{pCEP} 4-\mathrm{DCC}\right.$ vs. control pCEP4); ${ }^{*} \mathrm{p}=0.005$ (pCEP4-DCC vs. control C6lacZ); ${ }^{*} \mathrm{p}<0.05$ value indicates significance.

cells to a gradient of netrin-1. We also show that ectopic expression of DCC by C6 glioma cells slowed cell motility. These data are consistent with our previous report that DCC expression by human glioblastoma cells reduced motility [47]. In that study, we provided evidence that DCC promotes the formation of focal adhesions: however, the detailed mechanism underlying the capacity of DCC to restrain cell movement remains to be elucidated.

Here we show that rat C6 glioma cells are attracted up a gradient of laminin- 1 and that DCC expression slows the rate of tropic migration. Laminins are vital for tumor propagation and are an effective regulator of cell adhesion and migration $[59,60]$. As such, DCC may contribute to inhibiting the spread of an invading glial tumor. $\mathrm{C} 6$ cells secrete laminins, among other ECM components [56]. Glioma cell migration in the human brain typically follows pathways of ECM proteins that are enriched in the perivascular space and brain parenchyma [59]. Normal brain parenchyma, which is free of laminin [59], can produce laminin in response to invading glioma cells, 
and laminin deposits are present in the parenchyma in the vicinity of invading glioma cells [60]. Laminin-stimulated migration is integrin-based, and C 6 cells express integrin $a_{3} \beta_{1}[56]$, a laminin receptor that is frequently expressed in human glioma cells [60]. Interestingly, integrins $\alpha_{3} \beta_{1}$ and $\alpha_{6} \beta_{4}$ are reported to bind netrin-1 and function as netrin receptors [33]. Furthermore, netrin-1 signaling through DCC activates the integrin-associated kinase FAK to promote cell adhesion and migration $[22,61,62]$, raising the possibility that DCC and integrin signaling may interact.

C6 glioma cells express netrin-1 and netrin-3. Both netrin-1 and netrin-3 bind DCC and Unc5B [22], and it is likely that both proteins similarly contribute to the autocrine influence of netrin on C6 migration. Our findings support the hypothesis that netrins promote the growth of DCC-deficient C6 glioma, perhaps similarly to the growth-supportive activity of netrin-1 in DCC-lacking colon cancer cells [13]. In contrast, DCC expression suppressed $\mathrm{C} 6$ cell migration and tumor growth in vivo, inhibiting glioma cell dissemination and identifying DCC as a potential therapeutic target in glioma patients.

DCC signaling regulates cell migration, adhesion, and cytoskeletal dynamics [22]. Here, we have shown that DCCexpressing gliomas grow in vivo as a relatively compact cell mass, consistent with increased cell-cell interactions. Restoration of DCC function may re-engage a mechanism that normally acts to restrain cell motility by promoting cell adhesion. Receptors for ECM adhesion proteins, together with cytoskeletal-linked proteins, are responsible for organized cell migration [63]. DCC association with FAK, a principal tyrosine kinase of focal adhesions, suggests roles for DCC influencing cell attachment and detachment. Netrin-1 signaling through DCC also regulates src family kinases and the Rho family of small GTPases, that direct the dynamic organization of adhesions, the cytoskeleton, and thereby influence cell movement $[22,50,61,62,64,65]$. During glioma migration, activation of the src family kinase fyn and the GTPase Rac1 by integrin engagement, is regulated by the tyrosine phosphatase PTEN, a tumor suppressor that dephosphorylates FAK and is frequently deregulated in highly malignant tumors [66].

The Unc 5 family of netrin receptors signal chemorepulsion in response to netrin-1 [22]. Consistent with the findings we present here, they have also been shown to promote migration and cancer invasion in response to netrin-1 $[13,37,38]$. Expression of Unc5 homologues has been reported to be lost or reduced in several types of cancer [38-40,67], but not others [38]. Unc5B expression is detected in many tumor cell lines, including particularly strong expression in glioma [68]. Bearing in mind that DCC is lost in highly invasive glioblastoma multiform $[7,9,12]$, the response of glioma cells expressing Unc5B may become deregulated, causing them to migrate within the brain, but blocked from disseminating beyond the CNS by the repellent action of netrin-1 and laminin associated with the vasculature.

Major roles for netrins and netrin receptors have been identified during development and tissue morphogenesis $[21,31,34,43,69]$, during tissue regeneration after injury [37], and also in cell survival $[34,37,46,54,55]$. Coincidental loss of DCC with tumor progression suggests a role for DCC in the maintenance of tissue structure in adulthood. Our findings suggest that loss of DCC expression may destabilize a mechanism that normally restrains cell migration.

\section{Conclusions}

In summary, we provide evidence that autocrine secretion of netrins promotes $\mathrm{C} 6$ glioma cell migration, and that activation of Unc 5 homologue chemorepellent function may direct cells away from an expanding tumor mass. Our findings provide the first demonstration that the expression of DCC in highly malignant glioma cells can limit tumor growth in vivo. DCC reconstitution reduces cell motility and inhibits them from invading the surrounding brain tissue. Glioma treatment is compromised by tumor cell mobility and invasion. Our findings identify possible targets for the development of therapeutics to reduce glioma cell motility.

\section{Additional files}

Supplement figure S1

\section{Competing interests}

The authors declare that they have no competing interests.

\section{Authors' contributions}

Participated in research design: Durko M, Nalbantoglu J and Kennedy T.

Conducted experiments: Durko M, Koty Z, Zhu L and Marçal N. Performed data analysis: Durko M.

Wrote or contributed to the writing of manuscript: Durko M and Kennedy T.

\section{Acknowledgement}

We thank Dr. Joyce Rauch for critical review of the manuscript. Supported by a grant from the Canadian Institutes of Health Research (TEK). TEK was supported by a FRSQ Chercheur Nationaux award and as a Scholar of the Killam Trust.

\section{Publication history}

Editor: Jaydutt Virji Vadgama, UCLA School of Medicine, USA. Received: 29-Jan-2013 Revised: 24-May-2013

Accepted: 21-Jun-2013 Published: 25-Jul-2013

\section{References}

1. Maher EA, Furnari FB, Bachoo RM, Rowitch DH, Louis DN, Cavenee WK and DePinho RA. Malignant glioma: genetics and biology of a grave matter. Genes Dev. 2001; 15:1311-33. | Article | PubMed

2. Nakada M, Nakada S, Demuth T, Tran NL, Hoelzinger DB and Berens ME. Molecular targets of glioma invasion. Cell Mol Life Sci. 2007; 64:458-78. | Article I PubMed

3. Compagni A and Christofori G. Recent advances in research on multistage tumorigenesis. Br J Cancer. 2000; 83:1-5. | Article | PubMed Abstract | PubMed Full Text

4. Fearon ER, Cho KR, Nigro JM, Kern SE, Simons JW, Ruppert JM, Hamilton $\mathrm{SR}$, Preisinger AC, Thomas G, Kinzler KW and et al. Identification of a chromosome 18q gene that is altered in colorectal cancers. Science. 1990; 247:49-56. | Article | PubMed

5. Saito M, Yamaguchi A, Goi T, Tsuchiyama T, Nakagawara G, Urano T, Shiku 
$\mathrm{H}$ and Furukawa K. Expression of DCC protein in colorectal tumors and its relationship to tumor progression and metastasis. Oncology. 1999; 56:134-41. | Article | PubMed

6. Reale MA, Reyes-Mugica M, Pierceall WE, Rubinstein MC, Hedrick L, Cohn SL, Nakagawara A, Brodeur GM and Fearon ER. Loss of DCC expression in neuroblastoma is associated with disease dissemination. Clin Cancer Res. 1996; 2:1097-102. | Article | PubMed

7. Reyes-Mugica M, Lin P, Yokota J and Reale MA. Status of deleted in colorectal cancer gene expression correlates with neuroblastoma metastasis. Lab Invest. 1998; 78:669-75. | Article | PubMed

8. Saegusa M, Machida D and Okayasu I. Loss of DCC gene expression during ovarian tumorigenesis: relation to tumour differentiation and progression. Br J Cancer. 2000; 82:571-8. | Article | PubMed Abstract | PubMed Full Text

9. Meyerhardt JA, Look AT, Bigner SH and Fearon ER. Identification and characterization of neogenin, a DCC-related gene. Oncogene. 1997; 14:1129-36. | Article | PubMed

10. Reale MA, Hu G, Zafar Al, Getzenberg RH, Levine SM and Fearon ER. Expression and alternative splicing of the deleted in colorectal cancer (DCC) gene in normal and malignant tissues. Cancer Res. 1994; 54:4493501. | Article | PubMed

11. Reyes-Mugica M, Rieger-Christ K, Ohgaki H, Ekstrand BC, Helie M, Kleinman G, Yahanda A, Fearon ER, Kleihues P and Reale MA. Loss of DCC expression and glioma progression. Cancer Res. 1997; 57:382-6. | Article I PubMed

12. Ekstrand BC, Mansfield TA, Bigner SH and Fearon ER. DCC expression is altered by multiple mechanisms in brain tumours. Oncogene. 1995; 11:2393-402. I PubMed

13. Rodrigues S, De Wever O, Bruyneel E, Rooney RJ and Gespach C. Opposing roles of netrin-1 and the dependence receptor DCC in cancer cell invasion, tumor growth and metastasis. Oncogene. 2007; 26:561525. | Article | PubMed

14. Klingelhutz AJ, Hedrick L, Cho KR and McDougall JK. The DCC gene suppresses the malignant phenotype of transformed human epithelial cells. Oncogene. 1995; 10:1581-6. | Article | PubMed

15. VanZomeren-Dohm A, Sarro J, Flannery E and Duman-Scheel M. The Drosophila Netrin receptor frazzled/DCC functions as an invasive tumor suppressor. BMC Dev Biol. 2011; 11:41. | Article | PubMed Abstract | PubMed Full Text

16. Mehlen $P$ and Mazelin L. The dependence receptors DCC and UNC5H as a link between neuronal guidance and survival. Biol Cell. 2003; 95:42536. | Article | PubMed

17. Castets M, Broutier L, Molin Y, Brevet M, Chazot G, Gadot N, Paquet A, Mazelin L, Jarrosson-Wuilleme L, Scoazec JY, Bernet A and Mehlen P. DCC constrains tumour progression via its dependence receptor activity. Nature. 2012; 482:534-7. | Article | PubMed

18. Krimpenfort P, Song JY, Proost N, Zevenhoven J, Jonkers J and Berns A. Deleted in colorectal carcinoma suppresses metastasis in p53-deficient mammary tumours. Nature. 2012; 482:538-41. | Article | PubMed

19. Chan SS, Zheng H, Su MW, Wilk R, Killeen MT, Hedgecock EM and Culotti JG. UNC-40, a C. elegans homolog of DCC (Deleted in Colorectal Cancer), is required in motile cells responding to UNC-6 netrin cues. Cell. 1996; 87:187-95. | Article | PubMed

20. Keino-Masu K, Masu M, Hinck L, Leonardo ED, Chan SS, Culotti JG and Tessier-Lavigne M. Deleted in Colorectal Cancer (DCC) encodes a netrin receptor. Cell. 1996; 87:175-85. | Article | PubMed

21. Yee KT, Simon HH, Tessier-Lavigne M and O'Leary DM. Extension of long leading processes and neuronal migration in the mammalian brain directed by the chemoattractant netrin-1. Neuron. 1999; 24:607-22. Article I PubMed

22. Lai Wing Sun K, Correia JP and Kennedy TE. Netrins: versatile extracellular cues with diverse functions. Development. 2011; 138:215369. | Article | PubMed

23. Manitt C, Colicos MA, Thompson KM, Rousselle E, Peterson AC and Kennedy TE. Widespread expression of netrin-1 by neurons and oligodendrocytes in the adult mammalian spinal cord. J Neurosci. 2001; 21:3911-22. | Article | PubMed
24. Jarjour AA, Bull SJ, Almasieh M, Rajasekharan S, Baker KA, Mui J, Antel JP, Di Polo A and Kennedy TE. Maintenance of axo-oligodendroglial paranodal junctions requires DCC and netrin-1. J Neurosci. 2008; 28:11003-14. | Article | PubMed

25. Horn KE, Glasgow SD, Gobert D, Bull SJ, Luk T, Girgis J, Tremblay ME, McEachern D, Bouchard JF, Haber M, Hamel E, Krimpenfort P, Murai KK, Berns A, Doucet G, Chapman CA, Ruthazer ES and Kennedy TE. DCC expression by neurons regulates synaptic plasticity in the adult brain. Cell Rep. 2013; 3:173-85. | Article | PubMed

26. Baker KA, Moore SW, Jarjour AA and Kennedy TE. When a diffusible axon guidance cue stops diffusing: roles for netrins in adhesion and morphogenesis. Curr Opin Neurobiol. 2006; 16:529-34. | Article | PubMed

27. Srinivasan K, Strickland P, Valdes A, Shin GC and Hinck L. Netrin-1/ neogenin interaction stabilizes multipotent progenitor cap cells during mammary gland morphogenesis. Dev Cell. 2003; 4:371-82. | Article | PubMed

28. Moore SW, Correia JP, Lai Wing Sun K, Pool M, Fournier AE and Kennedy TE. Rho inhibition recruits DCC to the neuronal plasma membrane and enhances axon chemoattraction to netrin 1. Development. 2008; 135:2855-64. | Article | PubMed

29. Shekarabi M, Moore SW, Tritsch NX, Morris SJ, Bouchard JF and Kennedy TE. Deleted in colorectal cancer binding netrin-1 mediates cell substrate adhesion and recruits Cdc42, Rac1, Pak1, and N-WASP into an intracellular signaling complex that promotes growth cone expansion. $J$ Neurosci. 2005; 25:3132-41. | Article | PubMed

30. Moore SW, Biais N and Sheetz MP. Traction on immobilized netrin-1 is sufficient to reorient axons. Science. 2009; 325:166. | Article | PubMed Abstract | PubMed Full Text

31. Dalvin S, Anselmo MA, Prodhan P, Komatsuzaki K, Schnitzer JJ and Kinane TB. Expression of Netrin-1 and its two receptors DCC and UNC5H2 in the developing mouse lung. Gene Expr Patterns. 2003; 3:279-83. I Article I PubMed

32. Liu Y, Stein E, Oliver T, Li Y, Brunken WJ, Koch M, Tessier-Lavigne $M$ and Hogan BL. Novel role for Netrins in regulating epithelial behavior during lung branching morphogenesis. Curr Biol. 2004; 14:897-905. | Article | PubMed Abstract I PubMed Full Text

33. Yebra M, Montgomery AM, Diaferia GR, Kaido T, Silletti S, Perez B, Just ML, Hildbrand S, Hurford R, Florkiewicz E, Tessier-Lavigne $M$ and Cirulli $V$. Recognition of the neural chemoattractant Netrin-1 by integrins alpha6beta4 and alpha3beta1 regulates epithelial cell adhesion and migration. Dev Cell. 2003; 5:695-707. | Article | PubMed

34. Lu X, Le Noble F, Yuan L, Jiang Q, De Lafarge B, Sugiyama D, Breant C, Claes F, De Smet F, Thomas JL, Autiero M, Carmeliet P, Tessier-Lavigne $\mathrm{M}$ and Eichmann $\mathrm{A}$. The netrin receptor UNC5B mediates guidance events controlling morphogenesis of the vascular system. Nature. 2004; 432:179-86. | Article | PubMed

35. Leonardo ED, Hinck L, Masu M, Keino-Masu K, Ackerman SL and TessierLavigne M. Vertebrate homologues of C. elegans UNC-5 are candidate netrin receptors. Nature. 1997; 386:833-8. | Article | PubMed

36. Ly NP, Komatsuzaki K, Fraser IP, Tseng AA, Prodhan P, Moore KJ and Kinane TB. Netrin-1 inhibits leukocyte migration in vitro and in vivo. Proc Natl Acad Sci U S A. 2005; 102:14729-34. | Article | PubMed Abstract | PubMed Full Text

37. Wang W, Reeves WB and Ramesh G. Netrin-1 increases proliferation and migration of renal proximal tubular epithelial cells via the UNC5B receptor. Am J Physiol Renal Physiol. 2009; 296:F723-9. | Article | PubMed

38. Thiebault K, Mazelin L, Pays L, Llambi F, Joly MO, Scoazec JY, Saurin JC, Romeo $\mathrm{G}$ and Mehlen $\mathrm{P}$. The netrin-1 receptors UNC5H are putative tumor suppressors controlling cell death commitment. Proc Natl Acad Sci U S A. 2003; 100:4173-8. | Article | PubMed Abstract | PubMed Full Text

39. Bernet A, Mazelin L, Coissieux MM, Gadot N, Ackerman SL, Scoazec JY and Mehlen P. Inactivation of the UNC5C Netrin-1 receptor is associated with tumor progression in colorectal malignancies. Gastroenterology. 2007; 133:1840-8. | Article | PubMed Abstract | PubMed Full Text

40. Shin SK, Nagasaka T, Jung BH, Matsubara N, Kim WH, Carethers JM, 
Boland CR and Goel A. Epigenetic and genetic alterations in Netrin-1 receptors UNC5C and DCC in human colon cancer. Gastroenterology. 2007; 133:1849-57. | Article | PubMed

41. Kennedy TE, Serafini T, de la Torre JR and Tessier-Lavigne M. Netrins are diffusible chemotropic factors for commissural axons in the embryonic spinal cord. Cell. 1994; 78:425-35. | Article | PubMed

42. Serafini T, Colamarino SA, Leonardo ED, Wang H, Beddington R, Skarnes WC and Tessier-Lavigne M. Netrin-1 is required for commissural axon guidance in the developing vertebrate nervous system. Cell. 1996; 87:1001-14. | Article | PubMed

43. Alcantara S, Ruiz M, De Castro F, Soriano E and Sotelo C. Netrin 1 acts as an attractive or as a repulsive cue for distinct migrating neurons during the development of the cerebellar system. Development. 2000; 127:1359-72. | Article | PubMed

44. Hong K, Hinck L, Nishiyama M, Poo MM, Tessier-Lavigne $M$ and Stein E. A ligand-gated association between cytoplasmic domains of UNC5 and DCC family receptors converts netrin-induced growth cone attraction to repulsion. Cell. 1999; 97:927-41. | Article | PubMed

45. Colamarino SA and Tessier-Lavigne M. The axonal chemoattractant netrin-1 is also a chemorepellent for trochlear motor axons. Cell. 1995; 81:621-9. | Article | PubMed

46. Fitamant J, Guenebeaud C, Coissieux MM, Guix C, Treilleux I, Scoazec JY, Bachelot T, Bernet A and Mehlen P. Netrin-1 expression confers a selective advantage for tumor cell survival in metastatic breast cancer. Proc Natl Acad Sci U S A. 2008; 105:4850-5. | Article | PubMed Abstract I PubMed Full Text

47. Jarjour AA, Durko M, Luk TL, Marcal N, Shekarabi M and Kennedy TE. Autocrine netrin function inhibits glioma cell motility and promotes focal adhesion formation. PLoS One. 2011; 6:e25408. | Article | PubMed Abstract I PubMed Full Text

48. Meyerhardt JA, Caca K, Eckstrand BC, Hu G, Lengauer C, Banavali S, Look $A T$ and Fearon ER. Netrin-1: interaction with deleted in colorectal cancer (DCC) and alterations in brain tumors and neuroblastomas. Cell Growth Differ. 1999; 10:35-42. | Article | PubMed

49. Li H, Alonso-Vanegas M, Colicos MA, Jung SS, Lochmuller H, Sadikot AF, Snipes GJ, Seth P, Karpati G and Nalbantoglu J. Intracerebral adenovirusmediated p53 tumor suppressor gene therapy for experimental human glioma. Clin Cancer Res. 1999; 5:637-42. | Article | PubMed

50. Shekarabi $M$ and Kennedy TE. The netrin-1 receptor DCC promotes filopodia formation and cell spreading by activating Cdc42 and Rac1. Mol Cell Neurosci. 2002; 19:1-17. | Article | PubMed

51. Kennedy TE, Wang H, Marshall W and Tessier-Lavigne M. Axon guidance by diffusible chemoattractants: a gradient of netrin protein in the developing spinal cord. J Neurosci. 2006; 26:8866-74. | Article | PubMed

52. Wang H, Copeland NG, Gilbert DJ, Jenkins NA and Tessier-Lavigne M. Netrin-3, a mouse homolog of human NTN2L, is highly expressed in sensory ganglia and shows differential binding to netrin receptors. $J$ Neurosci. 1999; 19:4938-47. | Article | PubMed

53. Manitt C, Thompson KM and Kennedy TE. Developmental shift in expression of netrin receptors in the rat spinal cord: predominance of UNC-5 homologues in adulthood. J Neurosci Res. 2004; 77:690-700. | Article I PubMed

54. Llambi F, Causeret F, Bloch-Gallego E and Mehlen P. Netrin-1 acts as a survival factor via its receptors UNC5H and DCC. EMBO J. 2001; 20:2715-22. | Article | PubMed Abstract | PubMed Full Text

55. Mille F, Llambi F, Guix C, Delloye-Bourgeois C, Guenebeaud C, CastroObregon S, Bredesen DE, Thibert C and Mehlen P. Interfering with multimerization of netrin-1 receptors triggers tumor cell death. Cell Death Differ. 2009; 16:1344-51. | Article | PubMed Abstract | PubMed Full Text

56. Grobben B, De Deyn PP and Slegers H. Rat C6 glioma as experimental model system for the study of glioblastoma growth and invasion. Cell Tissue Res. 2002; 310:257-70. | Article | PubMed

57. Horn KE, Glasgow SD, Gobert D, Bull SJ, Luk T, Girgis J, Tremblay ME, McEachern D, Bouchard JF, Haber M, Hamel E, Krimpenfort P, Murai KK, Berns A, Doucet G, Chapman CA, Ruthazer ES and Kennedy TE. DCC expression by neurons regulates synaptic plasticity in the adult brain.
Cell Rep. 2013; 3:173-85. | Article | PubMed

58. Keleman K and Dickson BJ. Short- and long-range repulsion by the Drosophila Unc5 netrin receptor. Neuron. 2001; 32:605-17. | Article | PubMed

59. Giese $A$ and Westphal M. Glioma invasion in the central nervous system. Neurosurgery. 1996; 39:235-50; discussion 250-2. | Article | PubMed

60. Mahesparan R, Read TA, Lund-Johansen M, Skaftnesmo KO, Bjerkvig R and Engebraaten $\mathrm{O}$. Expression of extracellular matrix components in a highly infiltrative in vivo glioma model. Acta Neuropathol. 2003; 105:4957. | Article | PubMed

61. Ren XR, Ming GL, Xie Y, Hong Y, Sun DM, Zhao ZQ, Feng Z, Wang Q, Shim S, Chen ZF, Song HJ, Mei L and Xiong WC. Focal adhesion kinase in netrin-1 signaling. Nat Neurosci. 2004; 7:1204-12. | Article | PubMed

62. Liu G, Beggs H, Jurgensen C, Park HT, Tang H, Gorski J, Jones KR, Reichardt $\mathrm{LF}, \mathrm{Wu} J$ and Rao Y. Netrin requires focal adhesion kinase and Src family kinases for axon outgrowth and attraction. Nat Neurosci. 2004; 7:122232. | Article | PubMed Abstract | PubMed Full Text

63. Evers EE, Zondag GC, Malliri A, Price LS, ten Klooster JP, van der Kammen RA and Collard JG. Rho family proteins in cell adhesion and cell migration. Eur J Cancer. 2000; 36:1269-74. | Article | PubMed

64. Parsons JT, Martin KH, Slack JK, Taylor JM and Weed SA. Focal adhesion kinase: a regulator of focal adhesion dynamics and cell movement. Oncogene. 2000; 19:5606-13. | Article | PubMed

65. Li W, Lee J, Vikis HG, Lee SH, Liu G, Aurandt J, Shen TL, Fearon ER, Guan $\mathrm{JL}$, Han M, Rao Y, Hong K and Guan KL. Activation of FAK and Src are receptor-proximal events required for netrin signaling. Nat Neurosci. 2004; 7:1213-21. | Article | PubMed Abstract | PubMed Full Text

66. Dey N, Crosswell HE, De P, Parsons R, Peng Q, Su JD and Durden DL. The protein phosphatase activity of PTEN regulates SRC family kinases and controls glioma migration. Cancer Res. 2008; 68:1862-71. | Article | PubMed

67. Latil A, Chene L, Cochant-Priollet B, Mangin P, Fournier G, Berthon P and Cussenot $O$. Quantification of expression of netrins, slits and their receptors in human prostate tumors. Int J Cancer. 2003; 103:306-15. I Article I PubMed

68. Larrivee B, Freitas C, Trombe M, Lv X, Delafarge B, Yuan L, Bouvree K, Breant C, Del Toro R, Brechot N, Germain S, Bono F, Dol F, Claes F, Fischer C, Autiero M, Thomas JL, Carmeliet P, Tessier-Lavigne M and Eichmann A. Activation of the UNC5B receptor by Netrin-1 inhibits sprouting angiogenesis. Genes Dev. 2007; 21:2433-47. | Article | PubMed Abstract I PubMed Full Text

69. Navankasattusas S, Whitehead KJ, Suli A, Sorensen LK, Lim AH, Zhao J, Park KW, Wythe JD, Thomas KR, Chien CB and Li DY. The netrin receptor UNC5B promotes angiogenesis in specific vascular beds. Development. 2008; 135:659-67. | Article | PubMed Abstract | PubMed Full Text

\section{Citation:}

Durko M, Koty Z, Zhu L, Marçal N, Kennedy TE and Nalbantoglu J. Rat C6 glioma cell motility and glioma growth are regulated by netrin and netrin receptors unc5B and DCC. J Cancer Ther Res. 2013; 2:18. http://dx.doi.org/10.7243/2049-7962-2-18 